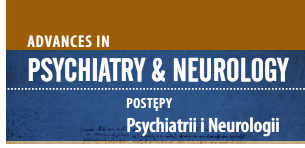

Correspondence to/

Adres do korespondencji:

dr Renata Wallner

Katedra i Klinika Psychiatrii

Uniwersytet Medyczny we Wrocławiu

ul. Pasteura 10

50-367 Wrocław, Polska

e-mail: renata.wallner@umed.wroc.pl

Submitted/Otrzymano: 26.11.2017

Accepted/Przyjęto do druku: 01.07.2018

\section{A MODEL OF TREATING POSTTRAUMATIC DISORDERS IN THE OPEN DIALOGUE APPROACH (ODA) EXEMPLIFIED BY THE COMMUNITY MENTAL HEALTH CENTRE (CMHC)}

MODEL LECZENIA ZABURZEŃ

POURAZOWYCH W PODEJŚCIU OTWARTEGO DIALOGU (ODA) NA PRZYKŁADZIE ŚRODOWISKOWEGO CENTRUM ZDROWIA PSYCHICZNEGO (ŚCZP)

\author{
Renata Wallner'1, Michał Klapciński² \\ 'Wrocław Medical University, Faculty of Postgraduate Medical Training, \\ Department of Psychiatry, Wrocław, Poland \\ ${ }^{2}$ Hospital of A. Sokołowski, Wałbrzych, Poland \\ 'Uniwersytet Medyczny im. Piastów Śląskich, Wydział Lekarski Kształcenia \\ Podyplomowego, Katedra Psychiatrii, Wrocław, Polska \\ ${ }^{2}$ Szpital Specjalistyczny im. A. Sokołowskiego, Watbrzych, Polska
}

\begin{abstract}
Purpose: The aim of this paper is to present current views on the meaning of trauma and its treatment by the use of Open Dialogue Approach (ODA). Authors broadly define trauma as mental crisis that urges an immediate and comprehensive care.

Views: Open Dialogue Approach with its demand on development of professional mental health structures not only meet the requirements imposed on community mental health centre (CMHC) as a core of the National Mental Health Program, but it seems to be exceptionally useful in the context of therapeutic work with traumatized patients and with people in a mental crisis. One of the main aspect of currently carried out mental health reform is the liberalization of hospital beds for those who are in severe mental crisis, substantially the raise od hospital standard for patients admitted to psychiatric hospital and to offer an ambulatory, easily accessible (local) ways of dealing with mental health problems.

Conclusions: At the core of the ODA lies a broad understanding of traumatic experience and broad perception of its symptomatic and processual consequences issuing mental crisis, which requires a fast, diverse and coordinated care. ODA may be defined as an integrative and community-oriented model of mental health service that follows constantly changing patients' needs. Available mental health structural frame - if well-coordinated - seems sufficient and could adequately respond to patient needs in the recovery process. Further prospective and methodologically well designed studies measuring method's treatment outcomes and cost-effectiveness should be conducted.
\end{abstract}

Key words: Open Dialogue Approach (ODA), community mental health center, trauma.

\title{
Streszczenie
}

Cel: Celem pracy jest przedstawienie podejścia otwartego dialogu (open dialogue approach - ODA), u podstaw którego leży szerokie rozumienie doświadczenia traumatycznego i jego konsekwencji. Trauma ujmowana jest zarówno w kontekście objawowym, jak i procesualnym jako kryzys psychiczny wymagający szybkiej, zróżnicowanej i skoordynowanej opieki.

Poglądy: Podejście otwartego dialogu poprzez propozycję rozbudowanej struktury instytucji pomocowych, tak jak ma to miejsce w przypadku modelu środowiskowego centrum zdrowia psychicznego (ŚCZP), oraz propozycję zintegrowanego i spójnego sys- 
A model of treating posttraumatic disorders in the Open Dialogue Approach (ODA) exemplified by the Community Mental Health Centre (CMHC) Model leczenia zaburzeń pourazowych w podejściu otwartego dialogu (ODA) na przykładzie środowiskowego centrum zdrowia psychicznego (ŚCZP)

temu oddziaływań, wydaje się w sposób naturalny odpowiadać różnorodnym potrzebom osób po traumatycznych doświadczeniach. Proponowany model ŚCZP wpisuje się w cele reformy leczenia psychiatrycznego i wprowadzenia leczenia środowiskowego. Rozszerzenie form pomocy i instytucji psychiatrycznych umożliwi zwolnienie miejsc w szpitalach psychiatrycznych dla osób, które rzeczywiście bezwzględnie wymagają hospitalizacji. Jednym z podstawowych celów reformy jest również poprawa dostępności leczenia ambulatoryjnego i szpitalnego oraz zmniejszenie przepełnienia w oddziałach szpitalnych, niespełniających standardów jakości leczenia we współczesnej medycynie.

Wnioski: Istotnym wyzwaniem w sytuacji reformy systemu opieki psychiatrycznej, która dokonuje się w Polsce, byłaby możliwość rozwijania całościowych modeli pomocy psychiatrycznej, opartych na szerokim rozumieniu kryzysów psychicznych i dostosowaniu oferty odpowiednich placówek pomocowych, a następnie przeprowadzenie poprawnych metodologicznie badań oceniających skuteczność proponowanych systemowych rozwiązań i ich efektywność.

Słowa kluczowe: podejście otwartego dialogu (ODA), środowiskowe centrum zdrowia psychicznego (ŚCZP), trauma.

\section{PURPOSE}

Initially, the Open Dialogue Approach (ODA) was used while working with patients treated for schizophrenia, which was comprehensively described in previous publications [1-5]. However, gradually, in the course of 30 years of experience with ODA, the group of persons with various experiences of mental crises for whom this approach proved to be useful was expanding. In the course of time, in medical environment and among patients in the psychiatric system of treatment the following questions can be heard louder and louder: "What is in fact a mental disorder or disease?" and "What language should be used to describe such difficult and complex phenomena as mental experiences?". These questions are often accompanied by numerous doubts. Previous approaches, biomedical in particular, related to numerous limitations in terms of treatment, do not cover the whole picture of human functioning, and even facilitate stigmatisation, both social and internalised. A critical approach to the previous narration as well as a broadened perspective while looking at a phenomenon, such as various mental disorders resulted in withdrawing from their traditional division into categories applied by medical/nosological classifications. From the point of view of therapeutic work, it is more useful to see mental disorders - including psychoses, phobias or depression - in the way suggested by the Open Dialogue, i.e. as a particular individual response to what happens in human relations with the social world. This response may assume a form of a profound mental crisis which externalises in various ways. However, this perspective does not question endogenic conditionings of mental disorders and a significance of the biological perspective, as well as the effect of pharmacotherapy. What is of special importance is extreme mindfulness and carefulness of medical professionals while naming the observed psychological phenomena which only appear to be well understood by us. Diagnoses which we applied in the biomedical model are of a pragmatic dimension, but also - which should be well-remembered - may limit and determine therapeutic procedures.

\section{CEL}

Początkowo podejście otwartego dialogu (open dialog approach - ODA) wykorzystywano w pracy z pacjentami leczonymi z powodu schizofrenii, co zostało szeroko opisane we wcześniejszych publikacjach [1-5]. Stopniowo jednak, w ciągu 30 lat doświadczeń ODA, krąg osób ze zróżnicowanymi doświadczeniami kryzysów psychicznych, wobec których podejście to okazało się przydatne, rozszerzał się. $Z$ biegiem czasu zarówno w środowisku medycznym, jak i wśród pacjentów korzystających z systemu leczenia psychiatrycznego coraz bardziej wybrzmiewały pytania: „Czym właściwie jest zaburzenie psychiczne/choroba psychiczna?” oraz „Jakiego języka należy używać do opisu tak trudnych i złożonych zjawisk jak przeżycia psychiczne?", a także wątpliwości z tym związane. Dotychczasowe ujęcia, zwłaszcza biomedyczne, podlegają licznym ograniczeniom w zakresie leczenia i nie uwzględniają całości obrazu funkcjonowania człowieka, a nawet sprzyjają stygmatyzacji zarówno społecznej, jak i zinternalizowanej. Krytyczne odniesienie się do dotychczasowej narracji i rozszerzenie perspektywy widzenia fenomenu, jakim są różnorodne zaburzenia psychiczne, spowodowało odchodzenie od tradycyjnego ujmowania ich w kategoriach przyjętych przez klasyfikacje medyczne/nozologiczne. Z punktu widzenia pracy terapeutycznej bardziej użyteczne wydaje się proponowane przez otwarty dialog spostrzeganie zaburzeń psychicznych, w tym psychoz, fobii, depresji, przede wszystkim jako swoistej indywidualnej odpowiedzi na to, co dzieje się w relacji człowieka ze środowiskiem. Odpowiedź ta może przybrać postać głębokiego kryzysu psychicznego, który uzewnętrznia się w różnorodnej postaci. Perspektywa ta jednak nie kwestionuje endogennych uwarunkowań zaburzeń psychicznych i znaczenia biologicznej perspektywy, a także znaczenia leczenia farmakologicznego. Istotna jest niezwykła uważność i ostrożność w przypadku nazywania przez profesjonalistów obserwowanych przez nas zjawisk psychicznych, które, jak się nam tylko wydaje, już dobrze rozumiemy. Diagnozy, które zwykło się stosować w modelu biomedycznym, mają swój wymiar pragmatyczny, ale też, o czym należy pamiętać, mogą ograniczać i determinować postępowanie terapeutyczne. 


\section{VIEWS}

In the history of mankind, the term "trauma" has functioned since man's first strife with the calamities and undertaken combat. The oldest records of psychological insight after traumatic experiences date back to the Sumerian Wars (2027-2003 BC) and they refer to symptoms which manifested in the inhabitants of war-stricken areas, i.e. the feeling of fear, helplessness and sleep disorders.

The concept of "trauma" was widespread mainly via literature, for instance in the works of Homer, William Shakespeare, Charles Dickens, Erich Maria Remarque, Kurt Vonnegut and many others. Memories of return voyages from wars by Odysseus, Henry IV - the king of England, or German soldiers during the World War I and II and the American soldiers coming back from Vietnam have a lot in common. They are accompanied by nightmares and avoiding traumatic situations. In the $17^{\text {th }}$ century, Robert Burton in his "Anatomy of Melancholy" referred to the effects of traumatic events on human psyche, and Samuel Pepys in his "Diary" described the traumatic events he himself experienced during the plague and the Great Fire of London. In the $19^{\text {th }}$ century, Charles Dickens had fallen a victim to a rail accident and the traumatic memories had assisted him until he died [6].

It is not difficult to observe that in the field of interest of psychological sciences and psychiatry, the phenomenon of trauma was neglected for a long time. Especially in the case of etiopathogenesis of psychoses, they were denied because it was believed that these disturbances were mainly biologically conditioned. Until the 1980s, the issue of trauma was not dealt with in the field of psychology, however, there were a few exceptions, i.e. the works of Martin Charcot, his disciple Pierre Janet and Sigmund Freud, who stressed the significance of after-effects of traumatic events. Both Charcot and Pierre Janet paid attention to the impossibility to integrate trauma-related memories which come back as living reminiscences, dreams or indispositions. Sigmund Freud and Pierre Janet pointed to conditionings of hysteria in psychological traumas, especially in sexual traumas in childhood [7]. Eugen Breuler, while studying the so-called "world of psychosis" of particular patients always saw their psychotic experience as an individual process of a response to a situation they live in and tried to interpret patients' statements by referring to their real experience [8].

In the field of medicine, as early as in the $19^{\text {th }}$ century, the effect of a war on physical and then mental condition of soldiers was observed. Doctor Jacob Mendes Da Costa described the outcomes in soldiers of the American Civil War which were later termed "soldier's heart" or "Da Costa syndrome". Similarly, surgeon John Eric

\section{POGLĄDY}

W historii człowieka pojęcie traumy funkcjonuje od czasów jego pierwszych zmagań z żywiołem i prowadzonymi walkami. Najstarsze opisy przeżyć psychicznych po traumatycznych doświadczeniach pochodzą z okresu wojen sumeryjskich (2027-2003 r. p.n.e.) i dotyczą objawów, które wystąpiły u mieszkańców terenów objętych wojną, tj. poczucie lęku, bezradności i zaburzenia snu.

Pojęcie traumy zostało szeroko rozpowszechnione głównie dzięki literaturze, choćby w dziełach Homera, Williama Szekspira, Charlesa Dickensa, Ericha Marii Remarque’a, Kurta Vonneguta i wielu innych. Wspomnienia powrotów do domu z wojny Odyseusza, Henryka IV króla Anglii czy też niemieckich żołnierzy podczas pierwszej i drugiej wojny światowej, amerykańskich żołnierzy powracających $z$ Wietnamu, mają wiele wspólnego. Towarzyszą im koszmary senne i unikanie sytuacji urazowych. W XVII w. Robert Burton w „Anatomii melancholii” nawiązywał do skutków zdarzeń traumatycznych mających wpływ na psychikę człowieka, a Samuel Pepys w swoim „Dzienniku” opisał przeżycia traumatycznych wydarzeń, których był obserwatorem podczas epidemii dżumy i wielkiego pożaru Londynu. Sam Charles Dickens w XIX w. stał się ofiarą katastrofy kolejowej i traumatyczne wspomnienia nie opuszczały go do końca życia [6].

Bez trudu można zauważyć, że w obszarze zainteresowania nauk psychologicznych i psychiatrii zjawisko traumy było długo zaniedbywane. Szczególnie w przypadku etiopatogenezy psychoz zaprzeczano im, ponieważ uważano, że zaburzenia te są przede wszystkim uwarunkowane biologicznie. Aż do lat osiemdziesiątych $\mathrm{XX}$ w. stosunkowo mało zajmowano się zagadnieniem traumy w obszarze psychologii, z nielicznymi wyjątkami, do których należą m.in. prace Jeana-Martina Charcota, jego ucznia Pierre’a Janeta oraz Zygmunta Freuda, w których podkreślano wagę następstw traumatycznych przeżyć. Zarówno Charcot, jak i Pierre Janet zwrócili uwagę na niemożność zintegrowania wspomnień dotyczących traumy, które powracają jako żywe wspomnienia, sny czy też w postaci gorszego samopoczucia. Zygmunt Freud oraz Pierre Janet wskazywali na uwarunkowania histerii w urazach psychicznych, szczególnie urazach seksualanych z okresu dzieciństwa [7]. Z kolei Eugen Breuler badając „świat obłędu” konkretnych chorych, widział ich psychotyczne doznania zawsze jako indywidualny proces w odpowiedzi na sytuację, w której żyją, i próbował dokonywać interpretacji wypowiedzi chorych, odnosząc się do ich doświadczeń z rzeczywistości [8].

$\mathrm{W}$ obszarze medycyny już w XIX w. dostrzegano wpływ wojny na stan fizyczny, a następnie psychiczny żołnierzy. Lekarz Jacob Mendes Da Costa opisywał skutki występujące u żołnierzy wojny secesyjnej, które nazwano „sercem żołnierskim” lub „sercem Da Costy”. Podobnie chirurg John Eric Erichsen opisał objawy psychiczne wy- 
A model of treating posttraumatic disorders in the Open Dialogue Approach (ODA) exemplified by the Community Mental Health Centre (CMHC) Model leczenia zaburzeń pourazowych w podejściu otwartego dialogu (ODA) na przykładzie środowiskowego centrum zdrowia psychicznego (ŚCZP)

Erichsen described the psychological symptoms in victims of accidences named an "Erichsen disease"; Hermann Oppenheim referred to them as "traumatic neurosis", and Emil Kraepelin defined them as "Schreckneurose". In the period of the Great War, a British army psychiatrist Charles Samuel Myers coined a term "shell-shock," comparing it to hysteria, and he treated this condition with hypnosis. In 1941, Abram Kardiner published his work "The Traumatic Neuroses of War" written on the basis of observations of his patients of the World Wars I and II. It may be a characteristic feature for the subject of trauma that it was avoided and omitted as much as it was only possible. However, after the World War II and further military conflicts, the Vietnamese War (1957-1975) in particular, it was impossible to ignore this phenomenon. Too many young men returned to the so-called "normal world" devastated, addicted to alcohol or drugs and unable to recover. Wartime veteran organisations faced a difficult issue, because - as can be seen in the studies conducted between 1986 and 1988 - in more than 30\% of the Vietnamese War veterans serious mental issues developed and maintained for years, i.e. depression, conduct disorders, personality disorders, substance dependences; and in more than 20\%, partial PTST was observed at a certain moment of their lives. This means that in more than a half of the Vietnamese War veterans (more than 1700000 people) "considerable symptoms of reaction to stress" were observed (Kulka, 1990) [9].

Since the second part of the 1990s, there was an intensive development in the field of studies which assessed the phenomenon of direct and remote symptoms that intensify after experienced psychological and physical traumas. For instance, an Australian study which compared persons suffering from schizophrenia in $1995(N=2031)$ with patients in $2013(N=1823)$ revealed some interesting aspects. As compared to 1995, in 2013 the percentage of tested persons in whom potential hereditary or genetic factors in schizophrenia development increased from $59 \%$ to $70 \%$, but, at the same time, in the study of 2013, a greater pathological role was played by all 4 dimensions of psychosocial life, the presence of which was confirmed in more than $85 \%$ in the studied group; dire straits in the childhood (reported in $88 \%$ of the studied patients from 1995 and $91 \%$ in 2013), earlier, intensified problems of everyday life (93\% and $94 \%$, respectively), a death of a close person ( $85 \%$ and $88 \%$, respectively) and an experience of trauma ( $85 \%$ and $87 \%$, respectively). Furthermore, this study revealed that the factors, which mostly predispose to the occurrence or relapse of mental disorders included earlier intensified problems of everyday life, i.e. a strong or chronic stress, family conflicts, problems in professional life, financial problems, childhood problems such as maltreatment or abuse, stępujące u ofiar wypadków, zwane „chorobą Erichsena”, Hermann Oppenheim posługiwał się pojęciem „nerwicy traumatycznej" (traumatic neurosis), a Emil Kraepelin określał je mianem „nerwicy z przerażenia” (Schreckneurose). Brytyjski psychiatra wojskowy Charles Samuel Myers w czasie pierwszej wojny światowej użył terminu „szok artyleryjski” (shell-shock), porównując go do histerii, i leczył go hipnozą. Abram Kardiner na podstawie obserwacji swoich pacjentów z pierwszej i drugiej wojny światowej w 1941 r. opublikował pracę pt. „Wojenna nerwica pourazowa” („The Traumatic Neuroses of War”). Może jest to właściwe dla tematu traumy, że właśnie go omijano i unikano tak dalece, jak to było tylko możliwe. Jednak po drugiej wojnie światowej i późniejszych konfliktach zbrojnych, zwłaszcza po wojnie w Wietnamie (1957-1975), było to już niemożliwe, aby zjawisko traumy zostało niezauważone. Zbyt wielu młodych ludzi powróciło do „normalnego” świata załamanych, uzależnionych od alkoholu lub narkotyków, nie mogąc się w nim odnaleźć. Organizacje weteranów stanęły przed trudnym problemem, ponieważ jak pokazują badania prowadzone w latach 1986-1988, u ponad 30\% weteranów wojny wietnamskiej rozwinęły się poważne problemy psychiczne utrzymujące się przez długie lata, tj. stany depresyjne, zaburzenia lękowe, zaburzenia zachowania, zaburzenia osobowości, uzależnienia, a u ponad $20 \%$ wystąpiły częściowe objawy stresu pourazowego (partial posttraumatic stress disorder - partial PTSD) w jakimś momencie ich życia. Oznacza to, że u ponad połowy wszystkich weteranów wojny w Wietnamie (ponad 1700000 osób) wystąpiły „znaczące objawy reakcji na stres” (Kulka, 1990) [9].

Coraz intensywniej - od drugiej połowy lat dziewięćdziesiątych XX w. - rozwijały się też badania oceniające zjawisko nasilających się bezpośrednich i odległych symptomów po przeżytych traumach psychicznych i fizycznych. $\mathrm{Na}$ przykład badanie porównujące osoby chorujące na schizofrenię w Australii z roku $1995(N=2031)$ z osobami chorującymi w roku $2013(N=1823)$ ujawniło interesujące aspekty. W roku 2013 w porównaniu z rokiem 1995 wzrósł odsetek osób badanych, u których wskazywano na potencjalne czynniki dziedziczne czy genetyczne w rozwoju schizofrenii z 59\% do 70\%, ale jednocześnie w badaniu z 2013 r. większą rolę patogenną zaczęły odgrywać wszystkie cztery wymiary życia psychospołecznego, których występowanie potwierdzano u ponad $85 \% \mathrm{w}$ grupie badanych: trudne problemy w dzieciństwie (raportowane u $88 \%$ badanych w 1995 r. i 91\% w 2013 r.), wcześniejsze nasilone problemy dnia codziennego (odpowiednio 93\% i 94\%), śmierć bliskiej osoby (odpowiednio 85\% i 88\%), doświadczenie traumy (odpowiednio 85\% i 87\%). Badanie to wykazało ponadto, iż czynnikiem najbardziej predysponującym do wystąpienia lub nawrotu zaburzeń psychicznych były wcześniejsze nasilone problemy dnia codziennego, np. silny lub przewlekły stres, konflikty rodzinne, problemy w pracy, trudności finansowe, problemy z dzieciństwa, 
a loss of one or both parents/guardians, coming from a broken home or toxic relations in the family [10].

On the other hand, a study of 2005 carried out on a population of the Japanese $(N=1596)$ showed that the most frequently reported and personally-significant cause of mental disturbances or a considerable mental crisis includes traumas related to difficult relations with others, and personal relations [11].

A similar tendency can be observed in the study carried out in the Republic of South Africa in 2003. What proved to play a crucial role in $83 \%$ of the studied participants was an intensified psychosocial stress consisting in serious professional or family problems or participation in excessive and chronically stressful life events and it was perceived as a possibly significant psychosis-triggering factor. $42.5 \%$ of persons expressed a belief that the symptoms they had experienced were mainly of biological nature, related to brain dysfunction or a hereditary disease [12].

It was only recently that the psychiatric society accepted the fact that even seemingly non-important traumas may be of a high psychological significance and affect the emergence of psychopathological symptoms. More and more attention has been paid to the role of psychosocial factors in the development of mental diseases, including psychoses, e.g. significant or repeated intensification of everyday-life stress, disturbed partner relationships, painful childhood experience related to family breaking, being the subject of humiliation, psychological or physical maltreatment. Thanks to numerous studies on factors which are related to the development of psychoses, the scientists have become interested in the issue of trauma and a burden it is linked with. This resulted in theoretical considerations on the manner in which experiencing trauma may increase a probability of development of posttraumatic psychotic symptoms in the form of delusions and hallucinations [23-25] as well as attempts to empirically verify formulated hypotheses $[26,27]$. It is probable that psychosis is a result of interactions among numerous factors among which the experience of trauma seems to be of a higher and higher significance. The studies of Kessler (1995) confirm the bidirectional nature of relations between trauma and mental disturbances, including posttraumatic psychoses. They also show that the development of PTSD is frequently preceded by a development of psychotic episodes [13]. Numerous studies on both clinical and non-clinical populations described a relation between trauma and psychotic symptoms [14-19]. The study of John Read, professor of clinical psychology of the Liverpool University showed that approximately 50\% of all persons with psychotic experiences underwent a severe psychological or physical trauma. Psychological trauma destroys the sense of identity, disturbs per- tj. bycie źle traktowanym czy wykorzystanym, utrata jednego lub obu opiekunów czy pochodzenie z rozbitej rodziny, toksyczne relacje w rodzinie [10].

Z kolei przeprowadzone w $2005 \mathrm{r}$. badanie na populacji Japończyków $(N=1596)$ wskazało - jako najczęściej zgłaszaną $\mathrm{i}$ istotną $\mathrm{z}$ osobistego punktu widzenia przyczynę wystąpienia zaburzeń psychicznych lub znacznego kryzysu psychicznego - traumy związane z poważnymi trudnościami $\mathrm{w}$ relacjach $\mathrm{z}$ innymi ludźmi, $\mathrm{w}$ tym relacjach osobistych [11].

Podobna tendencja daje się zauważyć w badaniu przeprowadzonym w RPA w 2003 r. U 83\% osób badanych istotne znaczenie miał nasilony stres psychospołeczny, polegający na poważnych trudnościach $\mathrm{w}$ pracy bądź $\mathrm{w}$ rodzinie, udziale $\mathrm{w}$ nadmiernych i przewlekle stresujących wydarzeniach życiowych, a także postrzegany jako możliwy znaczący czynnik wywołujący wystąpienie psychozy. W przypadku $42,5 \%$ osób wyrażano przekonanie, że doświadczane przez nich objawy mają głównie podłoże biologiczne, związane z zakłóceniem funkcjonowania mózgu lub chorobą dziedziczną [12].

Dopiero stosunkowo niedawno zaakceptowano w psychiatrii fakt, iż nawet pozornie mało istotne traumy mogą mieć duże psychologiczne znaczenie, wpływające na pojawienie się objawów psychopatologicznych. Zaczęto zwracać większą uwagę na rolę czynników psychospołecznych $\mathrm{w}$ powstawaniu zaburzeń psychicznych, w tym psychoz, np. znaczne lub powtarzające się nasilenie stresu dnia codziennego, zaburzone relacje w związkach, bolesne doświadczenia z dzieciństwa związane z rozpadem rodziny, bycie obiektem poniżenia, znęcania się psychicznego czy fizycznego. Dzięki coraz liczniejszym badaniom nad czynnikami mającymi związek z wystąpieniem psychozy, rośnie zainteresowanie badaczy zagadnieniem traumy i brzemieniem, jakie ona za sobą niesie. Doprowadziło to do teoretycznych rozważań nad tym, w jaki sposób doświadczenie traumy może zwiększać prawdopodobieństwo wystąpienia potraumatycznych objawów psychotycznych w postaci urojeń i halucynacji [23-25] oraz prób empirycznej weryfikacji stawianych hipotez [26, 27]. Jest prawdopodobne, że psychoza rozwija się jako wyniki interakcji między wieloma czynnikami, spośród których doświadczenie traumy wydaje się zyskiwać coraz większe znaczenie. Badania Kesslera (1995) potwierdzają dwukierunkowy charakter relacji między traumą a zaburzeniami psychicznymi, $\mathrm{w}$ tym potraumatycznymi psychozami. Wskazują także, iż wystąpienie PTSD często poprzedza rozwój epizodów psychotycznych [13]. Liczne badania w populacjach zarówno klinicznych, jak i nieklinicznych opisywały związek między traumą a objawami psychotycznymi [14-19]. Badania profesora psychologii klinicznej Johna Reada z University of Liverpool ujawniły, że około 50\% wszystkich osób z przeżyciami psychotycznymi doświadczyło ciężkiego urazu psychicznego lub fizycznego. Uraz psychiczny o charakterze traumy niszczy poczucie tożsamości, bezpieczeństwa, 
A model of treating posttraumatic disorders in the Open Dialogue Approach (ODA) exemplified by the Community Mental Health Centre (CMHC) Model leczenia zaburzeń pourazowych w podejściu otwartego dialogu (ODA) na przykładzie środowiskowego centrum zdrowia psychicznego (ŚCZP)

ception of the self and the world, intensifies the sense of fear by potentiating depressive affective states, which facilitates the occurrence of delusions and hallucinations. It can be observed in particular in a situation of a severe sexual abuse or maltreatment [20-25]. Scott et al. (2007) revealed extremely high, 10-times higher probability of a development of psychotic symptoms after a trauma [25]. Childhood traumas are strongly related to the presence of positive psychotic symptoms in patients diagnosed with psychotic episodes in non-clinical population. However, it is not understood whether the presence of trauma in the history of life may be linked with the presence of auditory hallucinations. It was confirmed in various studies that an experience of early-childhood trauma may probably be related to the development of positive psychotic symptoms (delusions, hallucinations), an increase of dissociative disorders, disorders in the perception of the self or anxiety disorders [26-30]. The recent study of E. Rub et al. (2015) confirmed that traumatic events positively correlate with the severity of positive symptoms and dysthymia, while they negatively correlate with the volume of the brain and hippocampus and cortisol level [31].

At present, the hypotheses are being verified regarding a relation between trauma and reported persecutory delusions, suicidal thoughts or auditory hallucinations. In the British cross-sectional study $(N=200)$ carried out by Freeman and Fowler (2009), a positive correlation was observed between an experience of trauma and the presence of persecutory delusions and hallucinations [40]. On the other hand, an experience of a serious sexual abuse or maltreatment was particularly linked with the presence of psychotic symptoms. The relation between trauma and paranoid symptoms was explained by, e.g., intensified level of experienced fear. At the same time, this study showed that trauma may have a non-specific effect on expressed delusions throughout the affective path, and these, in turn, may affect the development of hallucinatory experiences. However, the formulated hypotheses need to be further studied and confirmed in longitudinal studies. The above-described study was carried out on a representative group of adult Britons of the southern districts of London (20 000 households). The announcement was addressed by around 350 persons. The leaflets included information about the study carried out online at the King's College of London. An experience of at least one traumatic event in life was confirmed by $70 \%$ of respondents $(N=140)$. Childhood physical or sexual abuse constituted $25.5 \%$ of the studied persons $(N=51)$ out of which $7.5 \%$ reported serious sexual abuse $(N=15)$. $15 \%$ of the respondents reported an experienced trauma within the previous 12 months. The study confirmed the assumptions that occurrence of trauma in zaburza postrzeganie siebie i świata, nasila doświadczanie lęku, potęgując depresyjne stany afektywne, co pretenduje do wystąpienia urojeń i halucynacji. Jest to szczególnie zauważalne w sytuacji poważnego nadużycia seksualnego czy znęcania się [20-25]. Z kolei w badaniach Scotta i wsp. (2007) ujawniono bardzo wysokie, bo aż 10-krotnie większe prawdopodobieństwo wystąpienia objawów psychotycznych po doświadczeniu traumy [25]. Traumy z okresu dzieciństwa są wysoce powiązane $\mathrm{z}$ występowaniem pozytywnych objawów psychozy u pacjentów z rozpoznaniem epizodów psychotycznych w nieklinicznej populacji. Jednak nie wiadomo, czy obecność traumy w historii życia może być związana z występowaniem halucynacji słuchowych. W wielu badaniach potwierdzano, iż doświadczenie wczesnodziecięcej traumy może być wysoce prawdopodobnie powiązane $\mathrm{z}$ występowaniem pozytywnych objawów psychozy (omamy, halucynacje), wzrostem zaburzeń dysocjacyjnych, zaburzeń w obrazie siebie czy zaburzeń lękowych [26-30]. Ostatnie badania Ruba i wsp. (2015) potwierdziły, że traumatyczne wydarzenia pozytywnie korelują z nasileniem objawów pozytywnych i dystymii, natomiast negatywnie korelują $\mathrm{z}$ objętością mózgu i hipokampa oraz poziomem kortyzolu [31].

Aktualnie sprawdzane są na większych populacjach hipotezy o związku między traumą a wypowiadanymi urojeniami o charakterze prześladowczym, myślami samobójczymi czy halucynacjami słuchowymi. W badaniu przekrojowym przeprowadzonym w Wielkiej Brytanii $(N=200)$ przez Freemana i Fowlera (2009) zauważono dodatnią korelację między doświadczeniem traumy a występowaniem urojeń o typie prześladowczym i halucynacji [40]. Natomiast przeżycie poważnego nadużycia seksualnego i znęcania się były szczególnie powiązane z wystąpieniem objawów psychotycznych. Związek między traumą a objawami paranoicznymi był tłumaczony m.in. nasilonym poziomem odczuwanego lęku. Badanie to pokazało jednocześnie, że trauma może mieć niespecyficzny wpływ na wypowiadane urojenia poprzez drogę afektywną, a te z kolei mogą mieć wpływ na wywoływanie doznań omamowych. Wysunięte hipotezy wymagają jednak dalszego sprawdzenia w badaniach podłużnych. Opisane badanie przeprowadzono na reprezentatywnej grupie dorosłych Brytyjczyków z południowych dzielnic Londynu (20 tys. domostw). Na ogłoszenie odpowiedziało około 350 osób. W broszurach zawarta była informacja o badaniach online prowadzonych w King's College London. Doświadczenie co najmniej jednego wydarzenia traumatycznego w ciągu życia potwierdziło $70 \%$ respondentów $(N=140)$. Nadużycie w dzieciństwie o charakterze fizycznym czy seksualnym podało $25,5 \%$ badanych $(N=51)$, z czego $7,5 \%$ raportowało poważne nadużycia seksualne $(N=15)$. Z kolei $15 \%$ ankietowanych podało, że doświadczyło traumy w minionych 12 miesiącach. Badanie to potwierdziło przypuszczenia, iż wystąpienie traumy w ciągu całego życia jest powszechne w populacji. Aż $70 \%$ badanych potwierdza doświadczenie 
the whole life is common in the population. $70 \%$ of the respondents confirm the experience of trauma, which is a higher result as compared to the results obtained in extensive epidemiological studies (Kessler et al., 1995; Perkonigg et al., 2000; Breslau, 2002) [12]. The aim of the study was not to estimate the frequency of trauma in a population but to identify relations between traumas and symptoms of psychotic disorders. An experience of a traumatising event was linked with almost 5-times higher risk of auditory hallucinations and around 2.5-time higher risk of persecutory delusions. These results correspond to a previous study carried out by Campbell and Morrison (2007) and Gracie et al. (2007) [32, 33]. It was proved in the studied group that experiencing psychosis was more strongly linked with a serious childhood sexual abuse and events of a "perpetrator-victim" nature than in the case of natural disasters. Trauma may have a manifold effect on persecutory convictions and experienced hallucinations. The previously-cited study proved a strong relation between experienced anxiety, tension and fear and persecutory convictions (Freeman and Freeman, 2008). Severe anxiety resulting from traumatic experience is frequently related to paranoid convictions (e.g. Martin and Peen, 2001) or persecutory delusions, which is also described by Freeman and Garety (1999) [34-36].

The studies on trauma suggest a bidirectional relation between a trauma and an affective, anxiety-related or psychotic symptom. Severe stress strengthens depressive or anxiety-related experience of the self which brings a patient closer to delusional convictions regarding the self, but also the perceptions of the self - by their traumatising nature - intensify the depressive or anxiety-related effect. The relation between trauma and psychotic disorders is most clearly visible in the content of delusions. There are premises that the nature of intrusions and flashbacks is reflected in the content of hallucinations.

\section{The Model of Community Mental Health Centre (CMHC) in the treatment of traumatised persons}

The Open Dialogue Approach - in order to address the needs of persons in a mental crisis or suffering from mental diseases and also of those who suffer from various types of trauma - offers to apply the Model of Community Mental Health Centre (CMHC). The Model is based on assumptions of the co-ordinated support system. A person in a mental crisis, due to various conditions and barriers, does not have to go to a mental institution and often experience additional hospitalisation-related trauma or face iatrogenic procedures or diagnoses which stigmatise this person and the person's closest and relatives for the rest of their lives. Hospitalisation seems to be a solution of the last resort and should be limited to necessary traumy, co jest wyższym wynikiem niż te, które uzyskiwano $\mathrm{w}$ dużych badaniach epidemiologicznych (Kessler i wsp., 1995; Perkonigg i wsp., 2000; Breslau, 2002) [12]. Celem badania jednak nie było oszacowanie częstości występowania traumy w populacji, lecz zidentyfikowanie związków między traumą a przejawami zaburzeń o charakterze psychotycznym. Doświadczenie traumatyzującego wydarzenia było związane z blisko 5 razy większym ryzykiem wystąpienia halucynacji słuchowych i około 2,5 raza większym ryzykiem wystąpienia przekonań o charakterze deluzyjnym. Wyniki te pokrywają się z wcześniejszymi badaniami przeprowadzanymi przez Campbell i Morrison (2007) oraz Gracie i wsp. (2007) [32, 33]. W badanej grupie udowadniano, że doświadczenie psychozy było silniej powiązane z poważnym nadużyciem seksualnym w dzieciństwie i wydarzeniami, w których występowała relacja sprawca - ofiara, niż w przypadku katastrof naturalnych. Trauma może wpłynąć $\mathrm{w}$ wieloraki sposób na przekonania prześladowcze oraz doświadczanie halucynacji. Poprzednio cytowane badania udowodniły silny związek między przeżywanym niepokojem, napięciem i lękiem a przekonaniami prześladowczymi (Freeman i Freeman, 2008). Nasilony niepokój w następstwie traumatycznych doświadczeń jest często wiązany z przekonaniami paranoicznymi (np. Martin i Peen, 2001) czy urojeniami prześladowczymi, co opisują także Freeman i Garety (1999) [34-36].

Badania nad traumą wskazują na dwukierunkowy związek urazu z charakterem objawu afektywnego, lękowego lub psychotycznego. Ciężki stres wzmacnia depresyjne lub lękowe przeżywanie siebie, zbliżając pacjenta do urojeniowych przekonań na temat własnej osoby, ale również wyobrażenia na swój temat, a poprzez ich traumatyzujący charakter pogłębiają depresyjny lub lękowy afekt. Związek między traumą i zaburzeniem psychotycznym jest najbardziej dostrzegalny w treści doznań omamowych. Istnieją przesłanki przemawiające za tym, że charakter intruzji i flashbacków odzwierciedlany jest w treści halucynacji.

\section{Model środowiskowego centrum zdrowia psychicznego (ŚCZP) w leczeniu osób z doświadczeniem traumy}

Podejście otwartego dialogu, wychodząc naprzeciw potrzebom osób przeżywających kryzys psychiczny i chorujących psychicznie, także w wyniku doświadczenia różnych rodzajów traumy, proponuje wykorzystanie modelu środowiskowego centrum zdrowia psychicznego (ŚCZP). Model ten opiera się na założeniach skoordynowanego systemu wsparcia. Osoba w kryzysie psychicznym nie musi już, ze względu na różne uwarunkowania i bariery, trafiać do szpitala psychiatrycznego i przeżywać często dodatkową traumę, związaną z warunkami hospitalizacji oraz mierzyć się z jatrogennymi procedurami czy diagnozami, naznaczającymi ją i jej bliskich na całe życie. Pobyt w szpitalu wydaje się ostatecznym rozwiązaniem 
A model of treating posttraumatic disorders in the Open Dialogue Approach (ODA) exemplified by the Community Mental Health Centre (CMHC) Model leczenia zaburzeń pourazowych w podejściu otwartego dialogu (ODA) na przykładzie środowiskowego centrum zdrowia psychicznego (ŚCZP)

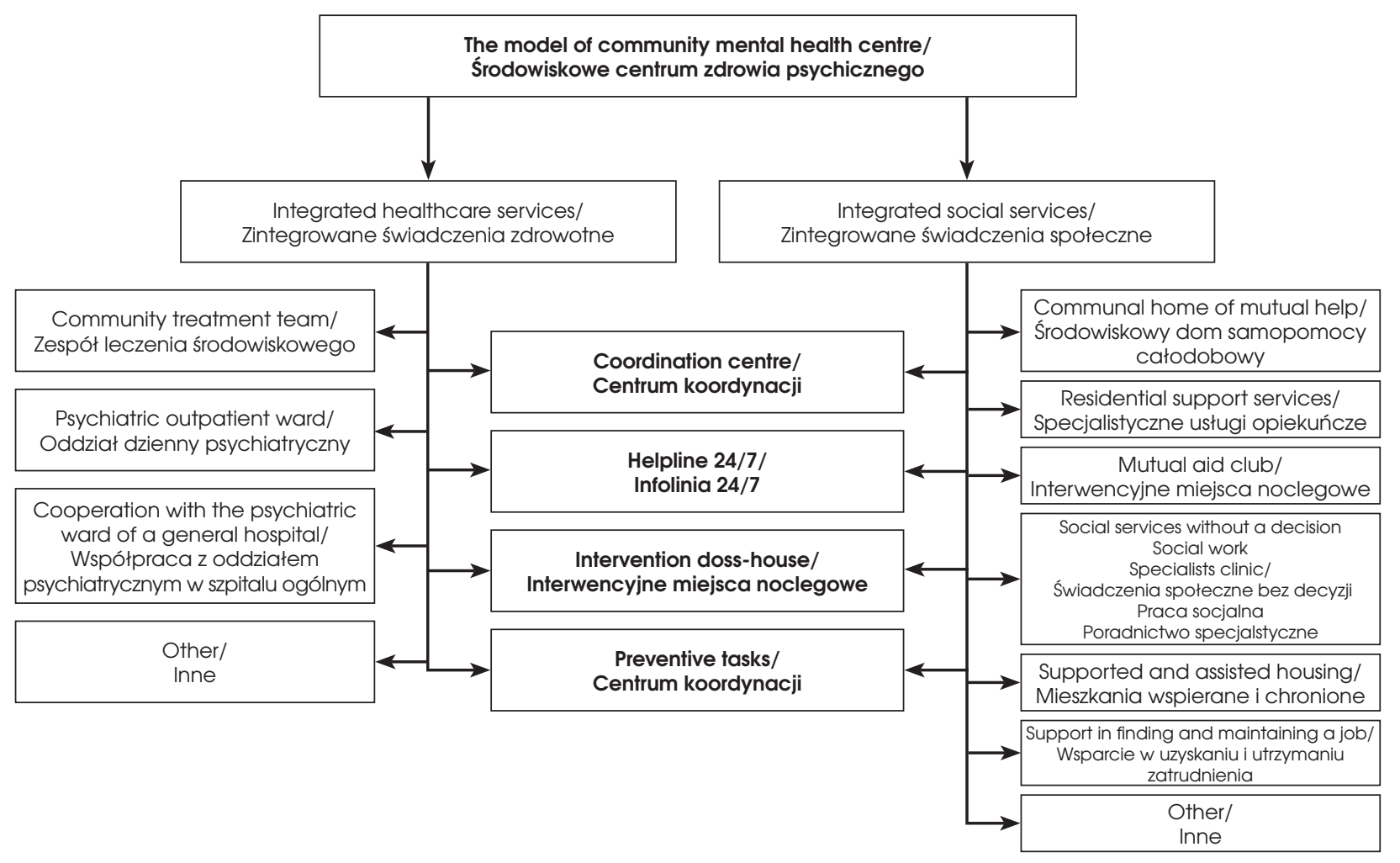

Figure I. The Model of Community Mental Health Centre (CMHC) structure, which applies the Open Dialogue Approach in a help situation towards persons after traumatic experiences

Rycina I. Model struktury środowiskowego centrum zdrowia psychicznego wykorzystującego podejście otwartego dialogu w sytuacji pomocowej wobec osób po doświadczeniach traumatycznych

and justified minimum. A person in a mental crisis could first and foremost use the services provided by other, more available than before, support centres which would function in an integrated way.

The following part of this paper presents a structural model of the CMHC based on the therapeutic approach of Open Dialogue (Figure I) [37].

The Open Dialogue Approach assumes that actions within the CMHC should be diversified in terms of their effects and manners of work (mobile teams, crisis intervention centres, hostels, assisted living housing, occupational therapy centres, outpatient units, community residential homes, hospital wards, cooperatives, educational and psychoeducational centres). Increasing access to persons who provide information or support ("Helpline 24/7") and then refer to adequate support centres is an important element of the system. A characteristic feature is a broadened offer of the so-called mobile teams which provide help both at the place of residence of a person in a crisis and also at the place indicated by such a person, e.g. an outpatient centre of a GP, an outpatient centre, community centre, an emergency centre. What constitutes the uniqueness of the work in the discussed therapeutic approach is taking into account the meetings of the social network of a person in crisis i powinien być ograniczany do koniecznego i uzasadnionego minimum. Osoba w kryzysie psychicznym przede wszystkim mogłaby skorzystać z usług wielu innych, bardziej dostępnych niż dotychczas placówek pomocowych, które funkcjonowałyby w sposób zintegrowany.

Poniżej przedstawiono model strukturalny ŚCZP w oparciu o podejście terapeutyczne otwartego dialogu (ryc. I) [37].

W podejściu otwartego dialogu zakłada się, iż wsparcie $\mathrm{w}$ ramach ŚCZP powinno odznaczać się różnorodnością oddziaływań i sposobów pracy (zespoły mobilne, ośrodki interwencji kryzysowej, hostele, mieszkania chronione, ośrodki terapii zajęciowej, oddziały dzienne, środowiskowe domy pomocy, oddziały szpitalne, spółdzielnie pracy, możliwość kształcenia i psychoedukacji). Istotnym elementem modelu jest zwiększenie dostępności do osób udzielających informacji lub wsparcia („telefon 24/7”), a następnie kierujących do odpowiednich placówek pomocowych. Cechą charakterystyczną jest bardziej rozbudowana oferta zespołów mobilnych, które udzielają pomocy zarówno w miejscu zamieszkania osoby w kryzysie, jak i w miejscu przez nią wskazanym, np. przychodnia lekarza rodzinnego, poradnia, centrum środowiskowe, ośrodek kryzysowy. Specyfiką pracy w omawianym podejściu terapeutycznym jest uwzględnianie 
and the use of social resources in coping with a mental crisis. It is recommended to increase cooperation with general practitioners and family doctors.

Therefore, an integrated and coordinated nature of work of particular centres and cooperation among them are necessary. Actions undertaken within the CMHC should be characterised by integrated medical, psychological and social help. A coordinated support system offered by professionals would focus on strengthening the resources of a person in a crisis and the person's social network after the experienced trauma. Another element in the treatment process is professionals' resignation from the expert position towards partnership cooperation which takes into account a dialogue approach and polyphony of all participants of the network.

Integration of persons experiencing mental crisis and the person's closest/relatives with social environment they function in, counteracting isolation, stigmatisation and social exclusion constitute the objectives and main challenges. Support centres should then concentrate their activity on forms of work which offer post-hospital social and professional activation.

The Open Dialogue Approach suggests looking at various mental disorders from diversified perspectives. Clinical manifestation, even the most complex one, may be perceived as a way of coping with a former or current trauma which contributes to the status of mental crisis. Many or even most people are capable of coming back to active life, working out the most optimal at a given stage of treatment coping strategies. The necessity of pharmacotherapy is not undermined here, or even isolation, as it is in the case of hospitalisation - if this is substantiated. The above rules are presented in the chart below (Figure II).

The institutional structure defined in the Open Dialogue Approach and presented on the basis of the CMHC model, which suggest certain integrated activities in diversified institutions (i.e. crisis intervention centre, assisted living housing, mental health centres, including specialised outpatient wards, mobile teams) as well as based on the basic principles of the Open Dialogue Approach (i.e. immediate help, inclusion of social network, flexibility, mobility, responsibility, continuity, cooperation), facilitates a more flexible and adequate adjustment to the reported needs regarding care and treatment of persons who need help and who are in a mental crisis. It seems justified that the time of hospitalisation at a mental hospital should be reduced to the necessary minimum. Mental hospital becomes then one of equivalent elements of the psychiatric healthcare system. It is desirable that after a period of necessary hospitalisation, a person in mental crisis, after withdrawal of acute symptoms and risk factors for life and health, has a chance to use the forms of community support (e.g. "the CMHC model"). Multidimension- spotkań sieci społecznej osoby w kryzysie i wykorzystanie zasobów społecznych $\mathrm{w}$ radzeniu sobie $\mathrm{z}$ kryzysem psychicznym. Zalecana jest większa współpraca $\mathrm{z}$ lekarzami pierwszego kontaktu, ogólnymi i rodzinnymi.

Wymagany jest zatem zintegrowany i skoordynowany charakter pracy poszczególnych ośrodków i współpracy pomiędzy nimi. Oddziaływania w ramach ŚCZP powinna cechować zintegrowana pomoc medyczna, psychologiczna oraz socjalna. Skoordynowany system wsparcia ze strony profesjonalistów koncentrowałby się na wzmacnianiu zasobów osoby po przeżytej traumie i jej sieci społecznej. Kolejnym elementem w procesie leczenia jest rezygnacja profesjonalistów z pozycji eksperta na rzecz partnerskiej współpracy uwzględniającej postawę dialogową i polifonię wszystkich uczestników sieci.

Celem i wyzwaniem jest integracja osób doświadczających kryzysu psychicznego i ich bliskich ze środowiskiem społecznym, w którym funkcjonują, przeciwdziałanie izolacji, stygmatyzacji i wykluczeniu społecznemu. Placówki pomocowe powinny w dalszej kolejności koncentrować swoją działalność na formach pracy oferujących pozaszpitalną aktywizację społeczną i zawodową.

Podejście otwartego dialogu proponuje spostrzeganie różnorodnych zaburzeń psychicznych z wielorakich perspektyw. Manifestację kliniczną, nawet najbardziej złożoną, można postrzegać jako jeden ze sposobów radzenia sobie z przeżytą lub przeżywaną traumą powodującą stan kryzysu psychicznego. Wiele lub nawet większość ludzi jest w stanie wrócić do aktywnego życia, wypracowując najbardziej optymalne na danym etapie leczenia strategie radzenia sobie. Nie podważa się w tym wypadku konieczności leczenia farmakologicznego, a nawet odosobnienia, tak jak to ma miejsce w przypadku hospitalizacji, jeśli jest ku temu merytoryczne wskazanie. Powyższe zasady zostały ujęte w schemacie przedstawionym na rycinie II.

Struktura instytucjonalna opisywana $\mathrm{w}$ podejściu otwartego dialogu, na przykładzie modelu ŚCZP, proponująca określone zintegrowane oddziaływania w różnorodnych instytucjach (tj. ośrodek interwencji kryzysowej, mieszkania chronione, poradnie zdrowa psychicznego, w tym specjalistyczne, oddziały dzienne, zespoły mobilne) oraz oparcie się na podstawowych zasadach podejścia otwartego dialogu (tj. natychmiastowa pomoc, włączenie sieci społecznej, elastyczność, mobilność, odpowiedzialność, ciągłość, współpraca), umożliwia bardziej elastyczne i adekwatne dostosowanie się do zgłaszanych potrzeb dotyczących opieki oraz leczenia osób potrzebujących pomocy i będących w kryzysie psychicznym. Wydaje się zasadne, aby czas pobytu $\mathrm{w}$ szpitalu psychiatrycznym redukować do niezbędnego minimum. Szpital psychiatryczny staje się wówczas jednym z równorzędnych elementów systemu opieki psychiatrycznej. Pożądane jest, aby po okresie niezbędnej hospitalizacji osoba w kryzysie psychicznym, po ustąpieniu ostrych objawów oraz czynników ryzyka zagrażających życiu i zdrowiu, miała moż- 
A model of treating posttraumatic disorders in the Open Dialogue Approach (ODA) exemplified by the Community Mental Health Centre (CMHC) Model leczenia zaburzeń pourazowych w podejściu otwartego dialogu (ODA) na przykładzie środowiskowego centrum zdrowia psychicznego (ŚCzP)

\begin{tabular}{|c|c|}
\hline & $\begin{array}{l}\text { Immediate help. A fast (up to } 48 \mathrm{~h} \text { ) intervention at an early stage of a crisis; a possibly short hospitalisation, } \\
\text { as fast as possible referral to community care/therapeutic centres; accessibility of a service to receive initial } \\
\text { calls (available Crisis Centre, helpline 24/7) } \\
\text { Natychmiastowa pomoc. Szybka (do } 48 \text { godzin) interwencja we wczesnej fazie kryzysu; możliwie krótka } \\
\text { hospitalizacja, jak najszybsze przekazywanie do środowiskowych form opieki/leczenia; dostępność punktu } \\
\text { przyjmującego zgłoszenia (dostępne Centrum kryzysowe, infolinia } 24 / 7 \text { ) }\end{array}$ \\
\hline & $\begin{array}{l}\text { Network-based approach. Meetings of social support network; resource-based; directing actions towards } \\
\text { a search for patient's/networks' resources and their application } \\
\text { Ukierunkowanie na sieć. Spotkania sieci wsparcia społecznego; oparcie na zasobach; ukierunkowanie } \\
\text { oddziaływań na poszukiwaniu zasobów pacjenta/sieci i ich wykorzystywanie }\end{array}$ \\
\hline & $\begin{array}{l}\text { Responsibility. A person who receives an initial call does not send a patient away to other entities/ } \\
\text { institutions but assumes a role of a coordinator } \\
\text { Odpowiedzialność. Osoba przyjmująca zgłoszenie nie odsyła pacjenta do innych podmiotów/instyłucji, } \\
\text { lecz przyjmuje rolę koordynatora }\end{array}$ \\
\hline & $\begin{array}{l}\text { Flexibility/mobility. Mobility of a therapeutic team; flexibility in choosing methods and manners of work; } \\
\text { individual and group therapy; other forms of participation in meetings; organising meetings wherever } \\
\text { it is possible (withdrawal from the approach that it is a client who comes for a visit) } \\
\text { Elastyczność/mobilność. Mobilność zespołu terapeutycznego; elastyczność w wyborze metod i sposobu } \\
\text { pracy; terapia indywidualna, grupowa, inne formy udziału w zajęciach; organizowanie spotkań tam, } \\
\text { gdzie to możliwe (odejście od podejścia, że to klient przychodzi do gabinetu) }\end{array}$ \\
\hline & $\begin{array}{l}\text { Polyphony and a dialogue. A common dialogue where specialists act as moderators and all participants } \\
\text { aim at understanding and agreement and then together work out solutions to their problems. Each voice } \\
\text { is equally important } \\
\text { Polifonia i dialog. Wspólny dialog, w którym specjaliści sq̨ moderatorami, a wszyscy uczestnicy dąża do } \\
\text { zrozumienia i porozumienia, następnie wspólnie wypracowują rozwiq̨zanie problemów. Każdy głos jest tak } \\
\text { samo ważny }\end{array}$ \\
\hline & $\begin{array}{l}\text { Embracing uncertainty. We cannot know what is good and proper for another person. We help to create } \\
\text { a space for development which will enable a speaker to make its own decisions } \\
\text { Tolerancja niepewności. Nie możemy wiedzieć, co jest dobre i właściwe dla drugiego człowieka. } \\
\text { Pomagamy stworzyć przestrzeń do rozwoju, która pozwoli rozmówcy na podjęcie własnych decyzji }\end{array}$ \\
\hline & $\begin{array}{l}\text { Cooperation. A partnership approach; withdrawing from an expert position. An institution for a patient; } \\
\text { cooperation among supporting institutions; cooperation with general practitioners and family doctors } \\
\text { Współpraca. Postawa partnerska; rezygnacja z pozycji eksperta; instytucja dla pacjenta; współdziałanie } \\
\text { instyłucji pomocowych; współpraca z lekarzami ogólnymi i rodzinnymi }\end{array}$ \\
\hline & $\begin{array}{l}\text { Psychological continuity. Possibly low number of changes in persons dealing with a patient; } \\
\text { an accompanying person throughout the whole process of treatment } \\
\text { Ciaggłość psychologiczna. Możliwie niewielka liczba zmian osób zajmujących się pacjentem; } \\
\text { osoba towarzysząca przez cały proces leczenia }\end{array}$ \\
\hline
\end{tabular}

Figure II. Principles of work of the $\mathrm{CMHC}$ to be applied in a help situation towards persons after traumatic events in the Open Dialogue approach

Rycina II. Zasady funkcjonowania ŚCZP, kłóre mogą zostać wykorzystane w sytuacji pomocowej wobec osób po doświadczeniach traumatycznych w podejściu otwartego dialogu

ality of the offered therapeutic help at different stages of the work with a person in a crisis is very important. Intervention and therapeutic work with a person after an experience traumatic event, and the person's closest/ relatives should consist in implementation of immediate help (preferably within 24-48 hours upon reporting such a need), emotional and social support, assuming the attitude of responsibility and continuity of action. On the other hand, the process of stabilisation, in which it is important to gain the feeling of safety, trust, un- liwość skorzystania ze środowiskowych form pomocy (np. model ŚCZP). Istotna jest wieloaspektowość proponowanej pomocy terapeutycznej na różnych etapach pracy z osobą w kryzysie psychicznym. Praca interwencyjna i terapeutyczna $z$ osobą po przeżytym doświadczeniu traumatycznym, a także z jej bliskimi, powinna polegać na wdrożeniu natychmiastowej pomocy (najlepiej w ciągu 24-48 godzin od zgłoszenia takiej potrzeby), wsparciu emocjonalnym i społecznym, przyjęciu postawy odpowiedzialności i ciągłości oddziaływań. Natomiast pro- 
derstanding and acceptance, is favoured by the application of dialogical approach therapy, based on building relations, assuming a non-directive role of a moderator/ therapist and resigning from an expert approach, embracing uncertainty in the process and not applying assessments or interpretations. Proposed in the Open Dialogue Approach activities of helping persons in a mental crisis which cover a coordination of a series of welfare centres for people after traumatic experiences is of a key role in all phases of support and treatment. An individual therapeutic plan is created and it takes into consideration defined, specific needs of a person in a mental crisis and the person's closest/relatives, and also a scope, character and intensification of these activities. From the very beginning, professionals who create a team (medical and therapeutic personnel) determine a further therapeutic plan together with a patient, paying special attention to defining the needs of a person in a crisis and possible resources for the patients and their social network to lean on while struggling with the crisis. Community mobile teams prove to be of special help since they provide services at the place of an initial call. An interdisciplinary nature of the team makes it possible to recognise a critical situation in a manner safe for the person who made the call and adequately direct further therapeutic actions, the scope of which is discussed with the patient and the patient's social network in the course of a consultation. Community mobile teams, due to their interdisciplinary nature and depending of the needs, may be composed of psychologists, social workers, psychotherapists, Ex-ins (persons who experienced their own crises and are adequately trained), psychiatrists and nurses. The practice shows that a system, which is adjusted to constantly changing needs, enables to provide the feeling of safety much faster, which makes it possible to initiate work on the trauma. An immediate and adequate help at an initial stage of the work with a person after a trauma is of a great significance for the prognosis and the recovery process. At the stage of trauma confrontation and integration, it is possible to both implement individual work and work with persons who support the therapeutic process using a series of available techniques.

Another element proposed in the Open Dialogue Approach is a close cooperation between mental health professionals and the doctors of primary health care. It is a bilateral cooperation; the primary health care doctors know about the existence of supporting structures, refer persons in need to a coordination centre and also invite mobile teams to interventions to their offices if need be. Additionally, attempts are undertaken to integrate the actions of welfare centres with medical and psychological services (continuous contact with welfare centres, social workers are members of mobile teams). cesowi stabilizacji, w którym istotne jest uzyskiwanie poczucia bezpieczeństwa, zaufania, zrozumienia i akceptacji, sprzyja dialogiczna postawa terapeutyczna, oparta na budowaniu relacji, przyjęciu niedyrektywnej roli moderatora/terapeuty i rezygnacja $\mathrm{z}$ postawy eksperta, a także na tolerowaniu niepewności w procesie, nieocenianiu i nieinterpretowaniu.

Proponowane przez podejście otwartego dialogu oddziaływania pomocy osobom w kryzysie psychicznym, obejmujące koordynację szeregu placówek opieki dla osób po doświadczeniu traumatycznym, ma kluczowe znaczenie we wszystkich fazach pomocy i leczenia. Tworzony jest indywidualny plan terapeutyczny uwzględniający określone, specyficzne potrzeby osoby w kryzysie psychicznym i jej bliskich, a także zakres, charakter i intensywność oddziaływań. Profesjonaliści, którzy stanowią zespół (personel medyczny i terapeutyczny), od samego początku wspólnie z pacjentem ustalają dalszy plan terapeutyczny, dużą uwagę skupiając na określeniu potrzeb osoby będącej w kryzysie i możliwych zasobów, na których pacjent wraz ze swoją siecią społeczną mogą się oprzeć. Bardzo przydatne okazują się środowiskowe zespoły mobilne, świadczące usługi w miejscu wezwania. Interdyscyplinarny charakter zespołu umożliwia w bezpiecznej dla zgłaszającego przestrzeni rozeznać się w sytuacji kryzysowej i odpowiednio dalej kierować działania terapeutyczne, których zakres jest omawiany z pacjentem i jego siecią w czasie spotkania konsultacyjnego. Środowiskowe zespoły mobilne, ze względu na swój interdyscyplinarny charakter i w zależności od potrzeb, mogą składać się zarówno z psychologów, jak i pracowników socjalnych, psychoterapeutów, „ex-inów” (osoby doświadczone po własnych kryzysach, odpowiednio przeszkolone), psychiatrów, pielęgniarek. Praktyka pokazuje, że system dostosowany do zmieniających się potrzeb pozwala znacznie szybciej zapewnić poczucie bezpieczeństwa, co umożliwia podjęcie pracy nad traumą. Niezwłoczna i adekwatna pomoc w początkowej fazie pracy $\mathrm{z}$ osobą po doświadczeniu traumy ma istotne znaczenie dla rokowania i procesu zdrowienia. W fazie konfrontacji z urazem oraz integracji urazu możliwa jest zarówno praca indywidualna, jak i z osobami wspierającymi proces terapeutyczny $\mathrm{z}$ wykorzystaniem szeregu dostępnych technik.

Kolejnym elementem proponowanym przez podejście otwartego dialogu jest ścisła współpraca profesjonalistów zdrowia psychicznego z lekarzami POZ. Jest to współpraca dwustronna: lekarze POZ wiedzą o istnieniu struktur pomocowych, kierują osoby potrzebujące do ośrodka koordynującego, jak również zapraszają zespoły mobilne na interwencje do swoich gabinetów w razie potrzeby; prowadzone są także starania o integrację oddziaływań pomocy społecznej, socjalnej z usługami medycznymi, psychologicznymi (stały kontakt z opieką społeczną, pracownicy socjalni członkami zespołów mobilnych). 
A model of treating posttraumatic disorders in the Open Dialogue Approach (ODA) exemplified by the Community Mental Health Centre (CMHC) Model leczenia zaburzeń pourazowych w podejściu otwartego dialogu (ODA) na przykładzie środowiskowego centrum zdrowia psychicznego (ŚCZP)

\section{CONCLUSIONS}

In the literature of the subject, the issue of trauma and the treatment of traumatic experiences in the Open Dialogue Approach has not been undertaken so far, despite the fact that it has been present in the Polish clinical professional practice as well as in training courses since 2012. So far, no reports of clinical trials have been published, although such research has been done in numerous centres and within various projects. It is a challenge to develop model programmes of psychiatric care in particular areas or in reference to defined groups of patients (e.g. youth, persons after a loss or acts of violence). The next step should be a proper methodological study to assess the efficacy of the proposed systemic solutions. Current conditions of the Polish psychiatric care are not sufficient to implement the full model of the CMHC, such as creation of mobile therapeutic teams which are to undertake early interventions, financing the services provided by two or more workers at the same time towards one patient or the patient's relatives, personalised budget for services, integrating the work of support centres, etc. The professionals who apply the Open Dialogue Approach in the Polish conditions observe measurable effects of their work as well as real benefits for patients and their closest. On the other hand, they need to struggle with fixed systemic framework, economic, legal and administrative limitations [38].

In the study carried out in Kainuu, in the course of a few years of observations done between 1992 and 1996 by Saari and Mauno [39], economic factors were assessed and compared together with psychological status and social functioning of patients who suffered from psychological disturbances and were treated within a "teamwork" in the Open Dialogue Approach and those treated within the conventional psychiatric care (hospitalisation and non-institutionalised). The study revealed that - in terms of the individual satisfaction assessment and family burden assessment - the work within the Open Dialogue approach was at least equally beneficial as it was in the traditional model, but from the economic perspective, it was cheaper than traditional psychiatric treatment (almost a threefold lower rate of hospitalisation days and more than twofold - of rehospitalisation), which constitutes an additional argument justifying the need to implement systemic changes in the psychiatric care system.

\section{WNIOSKI}

W literaturze przedmiotu nie podejmowano dotychczas tematu traumy i leczenia urazowych doświadczeń w podejściu otwartego dialogu, pomimo iż jest on obecny $\mathrm{w}$ praktyce klinicznej profesjonalistów praktykujących to podejście w Polsce od 2012 r. i podczas szkoleń. Nie opublikowano dotychczas doniesień z badań klinicznych, chociaż $\mathrm{w}$ wielu ośrodkach i w ramach projektów taka praca była i jest prowadzona. Stanowi to wyzwanie, aby rozwijać modelowe programy opieki psychiatrycznej w wybranych obszarach lub w odniesieniu do określonych grup pacjentów (np. młodzieżowych, po stracie, przemocy), a następnie przeprowadzić poprawne metodologicznie badania oceniające skuteczność proponowanych systemowych rozwiązań i ich efektywność. Obecne warunki polskiej opieki psychiatrycznej nie są odpowiednio przygotowane do realizacji w pełni modelu ŚCZP, np. poprzez tworzenie mobilnych zespołów terapeutycznych służących podejmowaniu wczesnej interwencji, finansowanie świadczenia udzielanego przez dwóch lub więcej pracowników jednocześnie na rzecz jednego pacjenta lub jego bliskich, spersonalizowanie budżetu świadczeń, zintegrowanie pracy placówek pomocowych itp. Profesjonaliści praktykujący podejście otwartego dialogu $\mathrm{w}$ polskich warunkach doświadczają wymiernych efektów swojej pracy oraz realnych korzyści dla pacjentów i ich najbliższych. $Z$ drugiej strony, zmagają się ze sztywnymi ramami systemowymi, ograniczeniami ekonomicznymi i prawno-administracyjnymi [38].

W badaniu w Kainuu w ciągu kilku lat obserwacji, przeprowadzanej w latach 1992-1996 przez Saari i Mauno [39], oceniano i porównywano wskaźniki ekonomiczne oraz stan psychiczny i funkcjonowanie społeczne pacjentów cierpiących na zaburzenia psychiczne, leczonych „zespołowo” w podejściu otwartego dialogu oraz leczonych $\mathrm{w}$ warunkach systemu konwencjonalnej psychiatrycznej opieki specjalistycznej (szpitalnej i nieinstytucjonalnej). Badania te wykazały, że praca w podejściu otwartego dialogu była w aspekcie oceny indywidualnego zadowolenia $z$ leczenia i obciążenia rodzinny co najmniej równie korzystna jak w modelu tradycyjnym, ale $\mathrm{w}$ aspekcie ekonomicznym tańsza niż tradycyjne leczenie psychiatryczne (blisko trzykrotnie niższy wskaźnik dni hospitalizacji i ponad dwukrotnie - rehospitalizacji), co jest dodatkowym argumentem uzasadniającym konieczność wprowadzania systemowych zmian w opiece psychiatrycznej. 


\section{Conflict of interest/Konflikt interesu}

Absent./Nie występuje.

Financial support/Finansowanie

Absent./Nie występuje.

\section{References/Piśmiennicłwo}

1. Seikkula J, Alakare B, Aaltonen J, Holman J, Rasinkangas A, Lehtinen V. Open dialogue approach: Treatment principles and preliminary results of a two-year follow-up study on first episode schizophrenia. Ethical Human Sciences and Services 2003; 5: 163-182.

2. Seikkula J, Alakare B, Aaltonen J. The Comprehensive Open-Dialogue Approach in Western Lapland: II. Longterm stability of acute psychosis outcomes in advanced community care. Psychosis 2011; 1-11.

3. Ulland D, Andersen AJ, Larsen IB, Seikkula J. Generating Dialogical Practices in Mental Health: Experiences from Southern Norway, 1998-2008. Administration and Policy in Mental Health 2013.

4. Aderhold V, Alanen Y, Hess G, Hohn P (Hrsg): Psychotherapie der Psychosen. Integrative Behandlungsansätze aus Skandinavien. Gießen (Psychosozial Verlag); 2003.

5. Seikkula J, Olson ME. Der Ansatz des Offenen Dialogs bei akuter Psychose: Seine 'Poetik' und 'Mikropolitik'. Zeitschrift für Systemische Therapie und Beratung 2006; 24: 183-197.

6. Makara-Studzińska M, Partyka I, Ziemecki P. Zespół stresu pourazowego - rys historyczny, terminologia, metody pomiaru. Curr Probl Psychiatry 2012; 13: 109-114.

7. Hustvedt A. Medical Muses: Hysteria in Nineteenth-Century Paris. Bloomsbury; 2011.

8. Scharfetter C. Bleuler Eugen, 1857-1939: Polyphrenie und Schizophrenie. Vdf Hochschulverlag AG; 2006, p. 30.

9. Kulka RA, et al. Trauma and the Vietnam War Generation: Report of Findings from the National Vietnam Veterans Readjustment Study. New York: Brunner/Mazel; 1990.

10. Commonwealth of Australia 2013. National Mental Health Report 2013. Online ISBN: 978-1-74241-926-8.

11. Tanaka G, Inadomi H, Kikuchi Y, Ohta Y. Evaluating community attitudes to people with schizophrenia and mental disorders using a case vignette method. Psychiatry Clin Neurosci 2005; 59: 96-101.

12. Hugo C, Boshoff D, Traut A, Zungu-Dirwayi N, Stein D. Community attitudes toward knowledge of mental illness in South Africa. Soc Psychiatry Psychiatr Epidemiol 2003; 38: 715-719.

13. Kessler RC, et al. Posttraumatic Stress Disorder in the National Comorbidity Survey. Archives of General Psychiatry 1995 (December); 52: 1048-1060.

14. Van Os J, Verdoux H. Diagnosis and classification of schizophrenia: categories versus dimensions, distributions versus disease. In: Murray RM, Jones PB, Susser E, van Os J, Cannon M (eds.). The Epidemiology of Schizophrenia. Cambridge: Cambridge University Press; 2003, p. 364-410.

15. Bebbington P, Bhugra D, Brugha T, Singleton N, Farrell M, Jenkins R, Lewis G, Meltzer H. Psychosis, victimisation and childhood disadvantage: evidence from the second British National Survey of Psychiatric Morbidity. British Journal of Psychiatry 2004; 185: 220-226. Bell V, Halligan PW, Ellis HD, 2006.

16. Read J, Agar K, Argyle N, Aderhold V. Sexual and physical abuse during childhood and adulthood as predictors of hallucinations, delusions and thought disorder. Psychology and Psychotherapy 2003; 76: 1-22.

17. Read J, van Os J, Morrison AP, Ross CA. Childhood trauma, psychosis and schizophrenia. Acta Psychiatrica Scandinavica 2005; 112: 330-350.

18. Scott JG, Nurcombe B, Sheridan J, McFarland M. Hallucinations in adolescents with post-traumatic stress disorder and psychotic disorder. Australasian Psychiatry 2007; 15: 4-48.

19. Scott J, Chant D, Andrews G, Martin G, McGrath J. Association between trauma exposure and delusional experiences in a large community-based sample. British Journal of Psychiatry 2007; 190: 339-343.

20. Read J, Bentall RP, Fosse R. Time to abandon the bio-bio-bio model of psychosis: Exploring the epigenetic and psychological mechanisms by which adverse life events lead to psychotic symptoms. Epidemiologia e Psichiatria Sociale 2009 (October-December); 18: 299-310. PMID 20170043.

21. Larkin W, Read J. Childhood trauma and psychosis: evidence, pathways, and implications. Journal of Postgraduate Medicine 2008; 54: 287-293, doi:10.4103/0022-3859.41437. PMID 18953148. Retrieved 5 April 2012.

22. Read J, Haslam N, Sayce L, Davies E. Prejudice and schizophrenia: a review of the mental illness is an illness like any other approach (PDF). Acta Psychiatrica Scandinavica 2009 (October-December); 114: 303-318, doi:10.1111/j.1600-0447.2006.00824.x. PMID 17022790. Retrieved 5 April 2012.

23. Read J, van Os J, Morrison AP, Ross CA. Childhood trauma, psychosis and schizophrenia: a literature review with theoretical and clinical implications (PDF). Acta Psychiatrica Scandinavica 2005 (November); 112: 330-350, doi:10.1111/j.1600-0447.2005.00634.x. PMID 16223421. Retrieved 5 April 2012.

24. Read J, Mosher L, Bentall R. Models of madness: psychological, social and biological approaches to schizophrenia. Brunner-Routledge; 2004.

25. Varese F, Smeets F, Drukker M, Lieverse R, Lataster T, Viechtbauer W, Read J, van Os J, Bentall RP. Childhood Adversities Increase the Risk of Psychosis: A Meta-analysis of Patient-Control, Prospective and Cross-sectional Cohort Studies. Schizophrenia Bulletin 2012 (March 29); 38: 661-671, doi:10.1093/schbul/sbs050. PMC 3406538free to read. PMID 22461484. Retrieved 13 April 2012. 
A model of treating posttraumatic disorders in the Open Dialogue Approach (ODA) exemplified by the Community Mental Health Centre (CMHC) Model leczenia zaburzeń pourazowych w podejściu otwartego dialogu (ODA) na przykładzie środowiskowego centrum zdrowia psychicznego (ŚCzP)

26. Misiak B, Moustafa AA, Kiejna A, Frydecka D. Childhood traumatic events and types of auditory verbal hallucinations infirst-episode schizophrenia patients. Comprehensive Psychiatry 2016; 66: 17-22.

27. Hacioglu Yildirim M, Yildirim EA, Kaser M, Guduk M, Fistikci N, Cinar O, et al. The relationship between adulthood traumatic experiences and psychotic symptoms in female patients with schizophrenia. Compr Psychiatry 2014; 55: 1847-1854.

28. Gallagher III BJ, Jones BJ. Childhood stressors and symptoms of schizophrenia. Clin Schizophr Relat Psychoses 2013; 7: 124-130.

29. Braehler C, Valiquette L, Holowka D, Malla AK, Joober R, Ciampi A, et al. Childhood trauma and dissociation in first-episode psychosis, chronić schizophrenia and community controls. Psychiatry Res 2013; 210: 36-42.

30. Schafer I, Fisher HL, Aderhold V, Huber B, Hoffmann-Langer L, Golks D, et al. Dissociative symptoms in patients with schizophrenia: relationships with childhood trauma and psychotic symptoms. ComprPsychiatry 2012; 53: 364-371.

31. Ruby E, Rothman K, Corcoran C, Goetz RR, Malaspina D. Influence of early trauma on features of schizophrenia. Early Interv Psychiatry 2015.

32. Gracie A, Freeman D, Green S, Garety PA, Kuipers E, Hardy A, Ray K, Dunn G, Bebbington P, Fowler D. The association between traumatic experience,paranoia and hallucinations: a test of the predictions of psychological models. Acta Psychiatrica Scandinavica 2007; 116: 280-289.

33. Campbell M, Morrison A. The relationship between bullying, psychotic-like experiences and appraisals in 14-16-year olds. Behaviour Research and Therapy 2007; 45: 1579-1591.

34. Freeman D, Fowler D. Routes to psychotic symptoms: Trauma, anxiety and psychosis-like experiences. Psychiatry Research 2009; 169: 107-112.

35. Freeman D, Garety PA, Bebbington PE, Smith B, Rollinson R, Fowler D, Kuipers E, Ray K, Dunn G. Psychological investigation of the structure of paranoia in a non-clinical population. British Journal of Psychiatry 2005; 186: 427-435.

36. Martin JA, Penn DL. Brief report: social cognition and subclinical paranoid ideation. British Journal of Clinical Psychology 2001; 40: 261-265.

37. Opis modelu leczenia środowiskowego zaburzeń psychicznych. W: Materiały z Projektu Power 4.1. Załącznik 3 Wzór opisu założeń modelu leczenia środowiskowego zaburzeń psychicznych. Fundacja Wspierania Rozwoju Społecznego „Leonardo” i Polski Instytut Otwartego Dialogu, 2017.

38. Krawczyk A, Solarz A, Wciórka J. Otwarty dialog w kryzysie psychotycznym. Med Prakt Psychiatria 2015; 2: 84-91, http://www.mp.pl/poz/psychiatria/inne_zaburzenia/117177,otwarty-dialog-w-kryzysie-psychotycznym.

39. Saari L, Mauno V, et al. Psychosis team in treatment of severe mental disorders in Kainuu in 1992-1996. Acta Universitatis Ouluensis.

40. Freeman D, Fowler D. Routes to psychotic symptoms: Trauma, anxiety and psychosis-like experiences. Psychiatr Res 2009; 169: 107-112. 